\title{
Determinants of the Capital Adequacy of U.S Financial Institutions
}

\author{
Melita Charitou \\ Associate Professor of Finance and Accounting, \\ Division of Finance and Economics, School of Business, University of Nicosia, Cyprus, \\ E-mail: charitou.m@unic.ac.cy
}

Received: Feb. 21, 2019 Accepted: March 16, 2019 Published: May 1, 2019

doi:10.5296/ifb.v6i1.14384 URL: http://dx.doi.org/10.5296/ifb.v6i1.14384

\begin{abstract}
In this study we examine the determinants of the capital adequacy ratios of the US financial institutions over the period 2012-2017. Using a dataset of 2135 bank-year observations, results show that financial institutions with high operating expenses as a percentage of revenues have lower capital adequacy ratios. This is an indication that bank inefficiencies are an impediment to robust capital adequacy ratios. Moreover, results show that more profitable banks have higher Capital Adequacy Ratios (CAR). Evidence shows that additional two risk related variables affect positively CAR, namely, earnings coverage of net charge off and loss allowance to loans. These results should be of great importance to bank executives, bank regulators and to major stakeholders such as investors and financial analysts, especially after the latest global financial crisis and the collapse of giant US financial institutions.
\end{abstract}

Keywords: financial institutions, capital adequacy ratios, Basel Accord 


\section{Introduction}

The global financial crisis led many financial institutions worldwide in financial distress, among those Washington Mutual, the largest commercial bank bankruptcy ever in US history. At the time of distress, the Federal Depository Insurance Corporation (FDIC) seized Bank's total assets of over $\$ 300$ billion and deposits of around 190\$ billion and made a deal with JP Morgan to acquire the failed bank for $1.9 \$$ billion. In an attempt to mitigate financial problems related to bank failures and thus stabilize the banking system, supervisory bodies, among those, the Bank for International Settlements (BIS) updated in 2013 the Basel III Accord, which is expected to be implemented fully in 2019. According to Basel Accords, financial institutions, should maintain minimum capital adequacy ratios. These ratios were proposed to ensure that banks have adequate funds to absorb potential loses and thus protect depositors and promote stability in the banking system (ElBannan, 2017; BIS, 2018; BCBS, 2010, 2016).

Several researchers in the U.S and internationally examined the factors that could potentially affect capital adequacy ratios, among those profitability, riskiness, efficiency and size with mixed and inconclusive results. For example, Sivarama, Krishnan and Sukar (2014) examined empirically various factors that may affect capital adequacy ratios. Results showed that firm size was the only factor that affects capital adequacy, whereas profitability, liquidity and asset quality were shown to be insignificant in explaining capital adequacy. Mili, Sahut, and Trimeche (2014), using a dataset of multinational banks, showed that bank's size is inversely related to Capital Adequacy Ratios (CAR) whereas some riskiness and profitability measures were shown to affect positively CAR. They also showed that some other profitability ratios, such as return on assets (ROA) do no affect CAR. Moreover, the findings of Ahmad, Ariff, and Skully (2008) showed positive association between non-performing exposures and CAR. On the other hand, size and the profitability measure net interest margin were shown to be inversely related to CAR.

The aim of this study is to examine four major categories of potential determinants of CAR, namely, profitability, efficiency, riskiness and bank size, by using all US National Commercial US financial institutions included in the FDIC. Our study differs from prior studies since we use a more recent and relatively large dataset of 2135 bank year observations to examine four major categories of potential determinants of CAR.

Our dataset consists of US national financial institutions collected from FDIC (Federal Deposit Insurance Corporation) over the period 2012-2017. Using a dataset of 2135 bank-year observations, results of this study show that profitability, as measured by ROA, affects positively bank's capital adequacy. These results imply that banks with higher revenues and lower expenses are those that have greater CAR. US national financial institutions with high operating expenses margin have lower capital adequacy ratios, implying that bank inefficiencies are an impediment to robust capital adequacy ratios. Furthermore, results show that riskiness, namely, earnings coverage of net charge off and loss allowance to loans, is positively associated with CAR, Finally, results show that bank size is negatively associated with CAR. 
The remainder of this paper is organized as follows. The next section reviews related literature, whereas section 3 describes research design, methodology, dataset and measurement of variables. Empirical results are discussed in section 5. Section 6 concludes the study.

\section{Literature Review and Hypotheses Development}

Banking plays a very important role in the economy. Robust banking systems lead to economic growth whereas weak banking may allow financial institutions to undertake riskier investments, in an attempt to increase shareholder's wealth. Downside risk of financial institutions could be threatening for the economy as a whole, since effects are systemic. In an attempt to mitigate those type of problems and thus protect depositors, regulatory bodies worldwide, among those the Bank for International Settlements (BIS), introduced various mechanisms through the Basel Accord. The Basel I Accord was initiated in the late 1980's, whereas Basel II was introduced in 2008. Unfortunately, this Accord did not prevent the financial crisis that took place in the late 2000's, since giant financial institutions failed or went into financial distress, among those, Washington Mutual, Lehman Brothers, IndyMac Bank, Bear Stearns (Estrella et al., 2000, Juca, 2012). To mitigate further the aforementioned problems, Basel III was introduced in 2013. The aim of this Accord was to enhance the banking regulatory framework, improve the banking sector's ability to deal with financial stress and strengthen the banks' transparency (BIS, 2018; BCBS, 2010, Schaek \& Cihak, 2012).

In an attempt to promote stability in the banking system and thus protect depositors, Basel Accord requires that financial institutions maintain minimum Capital Adequacy Ratios (CAR). Researchers tried to examine the factors that affect CAR, using various explanatory variables, among those, profitability, riskiness, bank size and efficiency. Empirical evidence regarding the factors that affect $\mathrm{CAR}$ has been mixed and inconclusive.

Using US data for a twenty year period, ending in 2012, Sivarama Krishnan and Sukar (2014) examined empirically the factors that affect CAR for US financial institutions. Evidence showed that bank size was inversely related to CAR whereas profitability, liquidity and riskiness, as measured by the quality of the asset portfolio, were shown to be statistically insignificant in explaining CAR. A study by Mili et al. (2014), using a dataset of multinational banks, examined empirically the factors that affect CAR. They used among other factors, macroeconomic factors as well as variables related to the bank's subsidiaries. Consistent with the Sivaraman et al study (2014), results showed that bank size is inversely related to CAR whereas profitability and riskiness, as measured by net interest margin and loan loss provisions, respectively, affect positively CAR. Evidence showed that profitability and riskiness measures, such as ROA and deposits to loans ratio, did not play any role in explaining CAR.

A study conducted prior to the 2008 global financial crisis by Ahmad, Ariff, and Skully (2008) showed that asset quality, as measured by non performing exposures (NPE) is positively 
related, whereas bank size and profitability measure net interest margin were shown to be inversely related to CAR. The evidence regarding bank size reconfirmed prior evidence whereas evidence regarding net interest margin has been inconsistent with prior literature, possibly due to the fact that financial institutions with high interest margins are those that undertake higher risk, which leads to lower asset quality and thus to higher non performing exposures. Aktas et al. (2015), using 71 European financial institutions over the period 2007-2012 showed that profitability as measured by ROA, riskiness, bank size and market volatility are statistically significant in explaining CAR. A study by Yahaya et al. (2016) reconfirmed prior evidence regarding the negative relation between bank size and CAR in Japan. As far as profitability and CAR is concerned, Ho and Hsu (2010), Bokhari et al. (2012), and Bateni et al. (2014) showed that there exists a positive relationship. On the other hand, Shingjergji and Hyseni (2015) provided evidence that profitability does not affect CAR. As far as riskiness and CAR is concerned, studies by Santos (2001) and Berger et al (2008) showed that risk is positively related to CAR.

Based on the aforementioned discussion, evidence shows that there exists inconclusive evidence regarding the factors that affect CAR. Using a more recent and much larger dataset of US National financial institutions over the period 2012-2017, this study aims to examine the factors that affect CAR.

The following hypotheses will be examined:

H1: There exists a positive relationship between profitability and Capital Adequacy Ratios (CAR).

H2: There exists a positive relationship between bank efficiency and Capital Adequacy Ratios (CAR).

H3: There exists a positive relationship between riskiness and Capital Adequacy Ratios (CAR).

H4: There exists a negative relationship between bank size and Capital Adequacy Ratios (CAR).

\section{Research Design}

\subsection{Dataset}

Our dataset consists of all US National Financial institutions that were included in the FDIC (Federal Deposit Insurance Corporation) database over the years 2012-2017. The FDIC is federal agency that insures deposits in U.S. banks in the event of a financial institution fails. The FDIC was created right after the 1929 stock market crash (specifically in 1933) to maintain public confidence and stability in the banking system. Our final dataset consists of 2135 bank-year observations. Consistent with prior literature, observations with absolute studentized residuals greater than 2 were considered outliers and were excluded from the final dataset. 


\section{MInstitute ${ }^{\text {Macrothink }}$}

\subsection{Empirical Models and Measurement of Variables}

In order to examine the determinants of the capital adequacy ratios of the US national financial institutions the following multivariate regression model will be used:

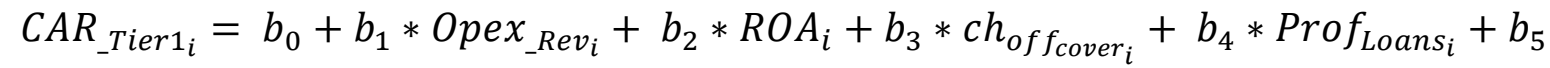

$$
\begin{aligned}
& \text { * } \text { Loans }_{\text {dep }_{i}}+b_{6} * \operatorname{LnT}_{i}+e_{i}
\end{aligned}
$$

The dependent variable is CAR_Tier1: capital adequacy ratio-Tier 1, Opex_Rev: operating expenses to revenue, ROA: Return on assets, Ch_Off_Cover: earnings coverage of net charge off, Prov_Loans: loss allowance to loans, Loans_Dep: net loans and leases to deposits, LnTA: natural logarithm of total assets. bo is the intercept term, $b_{i}$ : slope coefficient, $e_{i}$ : error term.

\section{Empirical Results}

\subsection{Descriptive Statistics}

Table 1 presents descriptive statistics for all variables used in the model. Results show that US national financial institutions have on average Tier 1 Capital adequacy ratios about $14.7 \%$ (median 13\%). The mean operating expenses as a percentage of the total revenues for those financial institutions is $67.9 \%$ (median 62.8\%). Their average Return on Assets (ROA) is $1.2 \%$ (median 1\%). The mean earnings coverage of net charge off is 0.89 (median 0.109). The mean loss allowance to loans and the net loans to deposits are 1.583 and 4.007 , respectively.

Table 1. Descriptive statistics

\begin{tabular}{lllll}
\hline Variables & Number of Observations & Mean & Median & Std. Deviation \\
\hline CAR_Tier1 & 2135 & 0.147 & 0.130 & 0.060 \\
Opex_Rev & 2135 & 0.679 & 0.628 & 1.724 \\
ROA & 2135 & 0.012 & 0.010 & 0.025 \\
Ch_Off_Cover & 2135 & 0.890 & 0.109 & 6.657 \\
Prov_Loans & 2135 & 1.583 & 1.239 & 1.317 \\
Loans_Dep & 2135 & 4.007 & 0.851 & 76.955 \\
LnTA & 2135 & 15.154 & 15.019 & 1.922 \\
\hline
\end{tabular}

In this table we present descriptive statistics results for all USA financial institutions for the period 2012-2017. The dependent variable is CAR_Tier1: capital adequacy ratio-Tier 1, Opex_Rev: operating expenses to revenue, ROA: Return on assets, Ch_Off_Cover: earnings coverage of net charge off, Prov_Loans: loss allowance to loans, Loans_Dep: net loans and leases to deposits, LnTA: natural logarithm of total assets.

\subsection{Correlation Analysis Results}

Table 2 presents Pearson correlation analysis results between all dependent and independent variables. These preliminary results show an indication of the relationship between Tier1 Capital Adequacy Ratios (CAR) and all independent variables. Results show that the greater the operating expense margin (Opex_Rev) the lower the CAR. On the other hand results 
show that profitability as measured with ROA is positively related to CAR. Moreover, results also show that there is a positive relationship between CAR and the following three variables, Ch_Off_Cover: earnings coverage of net charge off, Prov_Loans: loss allowance to loans, Loans_Dep: net loans and leases to deposits. Results also show that the independent variables are not highly correlated. The highest correlation among the independent variables is $28.1 \%$, which is an indication that there is no multicollinearity between the independent variables.

Table 2. Correlation Analysis

\begin{tabular}{llllllll}
\hline & CAR_Tier1 & Opex_Rev & ROA & Ch_Off_Cover & Prov_Loans & Loans_Dep & LnTA \\
\hline CAR_Tier1 & 1.000 & -.068 & .485 & .238 & .281 & .018 & -.209 \\
Opex_Rev & & 1.000 & -.121 & -.012 & .141 & -.011 & -.069 \\
ROA & & & 1.000 & .264 & .136 & .053 & -.041 \\
Ch_Off_Cover & & & & 1.000 & .000 & -.006 & -.009 \\
Prov_Loans & & & & & 1.000 & .044 & -.146 \\
Loans_Dep & & & & & & 1.000 & .009 \\
LnTA & & & & & & 1.000 \\
\hline
\end{tabular}

In this table we present Pearson correlation analysis results for all U.S. financial institutions for the period 2012-2017. The dependent variable is CAR_Tier1: capital adequacy ratio-Tier 1, Opex_Rev: operating expenses to revenue, ROA: Return on assets, Ch_Off_Cover: earnings coverage of net charge off, Prov_Loans: loss allowance to loans, Loans_Dep: net loans and leases to deposits, LnTA: natural logarithm of total assets.

\subsection{Regression Analysis Results}

Results in table 3 present multivariate analysis on the relationship between capital adequacy ratios (CAR_Tier1) and financial information for all US National financial institutions over the period 2012-2017. The number of firm-year observations used to get the results were 2135.

The following multivariate regression model was used to get the results presented in this table.

$$
\begin{aligned}
\text { CAR }_{\text {Tier } 1}= & b_{0}+b_{1} * \text { Opex }_{\text {Rev }}+b_{2} * R O A+b_{3} * \text { ch }_{\text {off } f_{\text {cover }}}+b_{4} * \text { Prof_Loans }+b_{5} \\
& * \text { Loans_dep }+b_{6} * \text { LnTA }+e
\end{aligned}
$$

Table 3. Regression Analysis

\begin{tabular}{llllll}
\hline & Coefficient & Std Error & t-value & Significance & VIF \\
\hline Opex_Rev & -0.002 & .001 & -3.202 & .001 & 1.045 \\
ROA & 0.972 & .045 & 21.718 & .000 & 1.124 \\
Ch_Off_Cover & 0.001 & .000 & 6.895 & .000 & 1.078 \\
Prov_Loans & 0.010 & .001 & 11.393 & .000 & 1.068 \\
Loans_Dep & 0.001 & .000 & -.649 & .516 & 1.005 \\
LnTA & -0.005 & .001 & -9.138 & .000 & 1.025 \\
Intercept & 0.198 & .009 & 22.238 & .000 & \\
\hline
\end{tabular}


Number of observations 2135

R-squared adj.

$32.4 \%$

In this table we present multivariate analysis results for all USA financial institutions for the period 2012-2017. The dependent variable is CAR_Tier1: capital adequacy ratio-Tier 1, Opex_Rev: operating expenses to revenue, ROA: Return on assets, Ch_Off_Cover: earnings coverage of net charge off, Prov_Loans: loss allowance to loans, Loans_Dep: net loans and leases to deposits, LnTA: natural logarithm of total assets.

As far as overall results is concerned, the F-value of the model is 171.6 and statistically significant with a p-value 0.000 . These results imply that the variables used in the model explain CAR. Moreover, the model's adjusted R-squared is 32.4\%. This means that the variables used in the model explain $32.4 \%$ in the variation of the Tierl CAR, which is relatively high, if we take into consideration that only 6 variables were used in the model. More specifically results show that four out of the five variables used in the model are statistically significant.

As far as hypothesis 1 is concerned which relates to the role of profitability in explaining CAR, results show that profitability, as measured with ROA, consistent with our expectations, is positively related to CAR That is, the greater the profitability, the greater the CAR. The coefficient of ROA is 0.972 and highly statistically significant $(a=0.000)$.

As far as hypothesis 2 is concerned which relates to the role of efficiency in explaining CAR, results show, consistent with our expectations, that the lower the operating profit margin (Opex_Rev) the lower the Tier1 CAR of the US financial institutions since the coefficient of this variable is negative $(-0.002)$ and statistically significant at $\mathrm{a}=0.001$. As far as hypothesis 3 is concerned which relates to the role of riskiness in explaining CAR, results show that the earnings coverage of net charge off (Ch_Off_Cover) is positively related to CAR. The coefficient of this variable is 0.001 and statistically significant $(\mathrm{a}=0.000)$. As far as loss allowance to loans is concerned, results show that there is a positive relationship with CAR. The coefficient of this variable is 0.010 and highly statistically significant $(a=0.000)$. Results show that the loans to deposits variable does not explain CAR (Altunbas et al., 2007). As far as hypothesis 4 is concerned which relates to the role of bank size in explaining CAR, results show that there is an inverse relationship, a result consistent with our expectations. Finally, results in this table show that there is no multicollinearity problem since Variance Inflation Factors (VIFs) are relatively low. Maximum VIF is 1.124 . Literature states that in order to have multicollinearity problems the VIF should be in excess of 10 .

In summary, results presented in this table provide strong evidence that four financial variables explain the variability of the Tier1 CAR.

\section{Conclusions}

In this study we examined the determinants of the capital adequacy ratios of US national financial institutions. Using a dataset of 2135 banks over the period 2012-2017, results show 
that financial institutions with high operating expenses as a percentage of revenues have lower capital adequacy ratios. This is an indication that bank inefficiencies are an impediment to robust capital adequacy ratios. Moreover, results show that more profitable banks, as measured by the ROA, have higher CAR. This means that firms with higher revenues and lower expenses are those that have greater CAR. Furthermore, results also show that additional two risk related variables, namely, earnings coverage of net charge off and loss allowance to loans, affect positively CAR, Finally, consistent to our expectations and to prior evidence, bank size is inversely related to CAR.

In summary, the results of this study have practical implications as well and should be of great importance to bank management, bank regulators and to the major stakeholders such as investors, financial analysts, since by understanding the determinants of the capital adequacy ratios, it will be easier to make decisions that create value for their organizations. As far as regulators is concerned, by understanding the determinants of CAR, they can pay more attention to those factors when evaluating financial institutions.

\section{References}

Ahmad, R., Ariff, M., \& Skully, M. J. (2008). The determinants of bank capital ratios in a developing economy. Asia-Pacific financial markets, 15(3-4), 255-272.

Aktas, R., Acikalin, S., Bakin, B., \& Celik, G. (2015). The Determinants of Banks' Capital Adequacy Ratio: Some Evidence from South Eastern European Countries. Journal of Economics and Behavioral Studies, 7(1), 79.

Altunbas,Y., S. Carbo, E. Gardener, P. Molyneux. (2007). Examining the relationships between capital, risk and efficiency in European banking, European Financial Management, 13(1), 49-70

Banking for International Settlements. (2018). Annual Economic Report 2018, June, Published by BIS.

Basel Committee on Banking Supervision (BCBS) (2010). Basel III: A global regulatory framework for more resilient banks and banking systems. Basel Committee on Banking Supervision, Basel.

Basel Committee on Banking Supervision (BCBS) (2016). Guidance on the application of the Core Principles for Effective Banking Supervision to the regulation and supervision of institutions relevant to financial inclusion.

Berger, A., DeYoung, R., Flannery, M., Lee, D. and Öztekin, Ö. (2008). How do large banking organizations manage their capital ratios? Journal of Financial Services Research, 34, 123-149.

Bateni, L., Vakilifard, H., \& Asghari. (2014). The Influential Factors on Capital Adequacy Ratio in Iranian Banks, International Journal of Economics and Finance, 6(11).

Bokhari, I. H., Ali, S. M., \& Sultan, K. (2012). Determinants of capital adequacy ratio in banking Sector: An Empirical analysis from Pakistan. Academy of Contemporary Research 
Journal, 2(1), 1-9.

ElBannan, M. (2017). The Financial Crisis, Basel Accords and Bank Regulations: An Overview. International Journal of Accounting and Financial Reporting, 7(2).

Estrella, A., Park, S., \& Peristiani, S. (2000). Capital ratios as predictors of bank failure. FRBNY Economic Policy Review, 6(2), 33-52.

Ho, S., \& Hsu, S.-C. (2010). Leverage, performance and capital adequacy ratio in Taiwan's banking industry. Japan and the World Economy.

Juca, M., Sousa, A., \& Fishlow, A. (2012). Capital Structure Determinant's of North American Banks and the Compensation Executive Program: An Empirical Study on the Actual Systemic Crisis. International Journal of Business and Management, Volume 7(17), 3-26.

Mili, M., Sahut, J., \& Trimeche, H. (2014). Determinants of the Capital Adequacy Ratios of a Foreign Bank's Subsidiaries: The Role of the Interbank Market and Regulation of Multinational Banks: IPAG Business School.

Santos, J. (2001). Bank capital regulation in contemporary banking theory: A review of the literature. Financial Markets, Institutions \& Instruments, December.

Schaek \& Cihak. (2012). Banking Competition and Capital Ratios. European Financial Management, 18(5), 836-866.

Shingjergii, A., \& Hyseni, M. (2015). The determinants of capital adequacy ratio in Albanian banking system during 2007-2014. International Journal of Economics, Commerce and Management, 3(1), 1-10.

Sivarama, K, \& Sukar, A. (2014). Capital ratios of US banks. International Journal of Business \& Economics Perspectives, 9(1).

Yahaya, S. N., Mansor, N., \& Okazaki, K. (2016). Financial Performance and Economic Impact on Capital Adequacy Ratio in Japan. International Journal of Business and Management, 11(4), 14-21.

\section{Copyrights}

Copyright for this article is retained by the author(s), with first publication rights granted to the journal.

This is an open-access article distributed under the terms and conditions of the Creative Commons Attribution license (http://creativecommons.org/licenses/by/4.0/). 